\title{
Singapore, Big Village of the Dead: Cities as Figures of Desire, Domination, and Rupture among Korowai of Indonesian Papua
}

Rupert Stasch

Division of Social Anthropology, University of Cambridge <rs839@cam.ac.uk>

American Anthropologist 118(2), June 2016.

\begin{abstract}
An important theme in the anthropology of space is that specific spatial forms often work for people as mediations of historical consciousness. I analyze here the example of cities in recent experience of Korowai of Papua, and I develop two theoretical points. First, a spatial form's power as a focus of consciousness rests in how it draws together multiple different elements of the historical field. In the example of Korowai thought about cities, these elements include "foreigners" as a type of people, consumer culture as an economic system, and urban superiority as a new social hierarchy. Second, a spatial form can be a powerful sign through which people engage specifically with emotional features of their historical condition, including emotional contradictions entailed in subjection to new hierarchies. I look at a striking Korowai pattern of associating cities with death, which I suggest is motivated by death and cities both being objects of contradictory feelings of simultaneous desire and repulsion, or involvement and separateness. The power of specific kinds of spaces to attract contradictory but conjoined emotions is also important to why people often seize upon them for reckoning cognitively with history at large.
\end{abstract}


Keywords: rural-urban articulations, space, structures of feeling, ethnic hierarchy, wealth, historical consciousness.

An important theme in comparative scholarship on space is that people often think about their general historical conditions by thinking about specific kinds of spaces (e.g. Herzfeld 1991; Sahlins 1992:17-35; Pandian 2009; Munn 2013[2004]). Raymond Williams wrote, for example, that "the contrast of the country and city is one of the major forms in which we become conscious of a central part of our experience and of the crises of our society" (1973:289). ${ }^{1}$ My subject here is is the elaborate attention given to urban space by Korowai people of Indonesian Papua, for whom the idea of a "city" is entirely new. Their situation thus represents one extreme of a widely-observed phenomenon of cities being vividly significant and consequential even to people who live at practical remove from them. More specifically, my example converges with earlier authors' demonstrations that rural people often directly perceive city space as a political institution, and that it is through ideas of geography that they conceptualize their positions in global social hierarchies. Thomas (2002), for instance, shows how in southeast Madagascar, "the river, the road, and the rural-urban divide" make up a "moral geography" by which villagers articulate their position in a wider political economy. Through geographic categories, they articulate feelings of exclusion from modernity's benefits, ambivalent stances of desire and repulsion toward urban "foreigners," and histories of domination and neglect by colonial and postcolonial states (compare also Ching and Creed 1997; Robbins 1998; 2008). 
Within this established problematic of spatial forms as sites of historical consciousness, I seek to advance two points that are also already present in the literature but deserve more development. One hoped contribution is to model an ethnographic examination of a spatial form as specifically a semiotic or relational entity. My ethnographic discussion will explicate several basic associations that cities hold for Korowai. To them, the city as a kind of space is a figure of foreign people. ${ }^{2}$ It is also a figure of those people's economic system. And it is a figure of Korowai speakers' own new temporal and political situation of evaluative inferiority in a new hierarchy. Some of these patterns of stereotypic association are again common around the globe. In underscoring the multiplicity of these wider historical presences merged in the city idea for Korowai, I argue that it is the spatial form's capacity to draw together diffuse and heterogeneous world conditions that gives it such appeal, as a focus of historical consciousness.

My second hoped contribution is to join this point about the dense historical relationality of a spatial form with issues of emotion and evaluation. The pattern of talk referenced by my title exemplifies the intensely emotional character of cities in Korowai consciousness. Besides associating cities with foreigners, capitalism, and hierarchy, Korowai also associate them with death. For about fifteen years, Korowai have been describing events of death as travel to a city. In the early 2000s, it became routine for ill persons to say on their deathbeds "I'm going to Wamena," “Oh, mother of my child, I'm leaving you, I'm taking off for my big village," or "I'm going to the big village, I'm going to Jayapura." ${ }^{3}$ Here "big village" (xampung-tale) is the Korowai term for cities in general, while Wamena and Jayapura are specific cities that Korowai know as faraway centers of commerce and air transport (Figure 1). More recently, Sinapol has become the standard "big 
village" where people are now said to go after death. Besides dying persons speaking of their own travel to a city, survivors also commonly describe a dead relative as having "left for the big village." Or to give one other example from the many expressive variations on this basic idea, a man explained to me that he had buried a relative by saying "It was I who put her in the big village," linking cities specifically to physical graves. In my extended discussions with a dozen or more people about statements in this vein (whether ones they made about someone else's death, or ones they had heard from the lips of a dying relative), it was usually clear that speakers and hearers understood the statements to be a direct, literal descriptions of an event of travel to a definite geographic place, as well as understanding the statements to describe something uncanny and shocking that the living cannot know with clarity. The overall fashion of speaking has stood out strikingly to me, due not only to its vivid and surprising imagery, but also to it having been innovated and conventionalized among Korowai within the time of my own fieldwork visits to them every few years since 1995.

Linking of cities and the dead of the sort considered here is a small pattern in the overall sweep of rural imaginings of the city worldwide, but such linkages have been previously documented among other indigenous, state-free peoples now on the periphery of urban colonial and postcolonial power formations, who have heritages of conceiving social relations between living and dead to be continuous with social relations among the living. Quichua speakers of lowland Ecuador describe spirit masters of forest animals as "white," as commanding industrial transport technologies and other utopian economic conditions, and as living in cities or towns inside hills on the local forest landscape (Kohn 2007). The highest master of animals lives in "Quito," inside the region's tallest volcano. The realm of 
spirit masters is also where the human dead reside in "free" conditions of youth and plenitude (Kohn 2013:106, 154-157, 182, 209). In the early 20th century, Kuna of Panama envisioned death as a spatial passage to an order where Indians possess the wealth and transport technologies of whites (Nordenskiöld and Kantule 1938:291; see also Taussig 1993:132). Linking cities and the dead is perhaps best known from literature on societies of Papua New Guinea (PNG), where it is an occasional motif within the more widely discussed pattern of linking the ancestral dead with whites and their wealth. In Matong village, adherents of the Kivung movement call their administrative house and its adjacent cemetery "City" (Kildea and Simon 2005; Lattas 2006). The house is a ritual space through which they seek positive relations with the dead that will rectify their exclusion from material wealth in the racialized geography of the colonial and post-colonial order. Writing about Ngaing people of PNG's north coastal region, Kempf and Hermann have documented a particularly rich range of elaborations on identification of cities as lands of the dead, such as the dream-based realization by a cohort of male initiates that the former taboo site in which they are secluded a bit outside their rural hamlet is actually a city (Kempf and Hermann 2003), and an older man's recollections of his 1984 journey to four increasingly holy destinations of the souls of the dead that are also a hierarchy of urbanization (Kempf 2009:62-64). According to this man, klinpaia resembles the local town of Madang, limbo is identified with the national capital of Moresby, pullkatori is "a perfectly holy place" that is "just like being in Australia," and heaven is "the place of the tiny children...without sin," while "Hell is where we are now-here on our land." During his regular conversations with souls of the dead across his later life, the man would query them about which location they were in. 
Kempf and Hermann may be the only authors who have offered a sustained interpretation of such linking of cities and the dead. ${ }^{4}$ They argue that Ngaing ideas in this vein, and living Ngaing people's practices of contact with death-associated city spaces through dreams, visions, and rituals, are ways they "enlarge" or "expand" their local landscape to global proportions, and conversely "mak[e] whiteness a component of the local world" (Kempf 1999; Kempf and Hermann 2003:81). The ideas and practices are in these ways a "subversive ordering of space," through which Ngaing foreground spatial categorization's direct entanglement with "exercise of power," and envision historical positions for Ngaing themselves different from what is offered by "hegemonic spatial configurations" (Kempf and Hermann 2003:81; Kempf 1999:110-111).

Korowai stereotypic associations of cities with foreigners, capitalist consumer culture, and political domination that I explore below are crucial in turn to addressing the cities' association with death. The interpretations of the Korowai idea of death as passage to a city that I ultimately propose will echo Kempf and Hermann's analysis, and build on work of other researchers on New Guineans' ideas of their relations to whiteness and wealth. What I hope to draw into stronger analytic view, relative to existing regional studies and to work in the anthropology of space generally, is again the structure of emotional experience evoked by a spatial form. The question of the city's prominence in Korowai consciousness is inseparable from a question of what history and hierarchy feel like. To ask what the city is for Korowai is to ask: What is the psychological structure of living with the harsh asymmetries and discontinuities of a position of deprivation relative to new urban others? The interpretation I develop is that Korowai alignment of cities with death i flourishes because cities and death are both objects of ambivalent, volatile 
emotions and evaluations. Death and cities systematically conjoin feelings of involvement or desire with feelings of separateness, deprivation, or fear. There has again been prior work on the evaluative volatility of rural-urban relations (e.g. Nandy 2007). Williams himself, through the category "structure of feeling," argued that history unfolds partly at the level of coordinated patterns of emotion and personal subjectivity not easily visible in propositional discourse and formal institutions. In The Country and the City, he examined (like other scholars) the systematic ambivalence of ideological formations of pastoral nostalgia, involving painfully pleasurable longing for a disappearing rural integrity. But current Korowai patterns, in vividly linking cities to death, and in being independent of sustained influence by metropolitan ideology, can give a renewed visibility to this fractured, contradictory character of psychological experience under specific historical conditions.

\section{City Connections and City Distance}

Until the 1980s, Korowai had no centralized settlements and no regular meetings with long-distance strangers. They lived in single or paired houses in garden clearings, separated by expanses of forest. This dispersion was motivated by dislike of anyone being in a position to tell others what to do (Stasch 2009:25; Stasch 2015a). Today Korowai alternate between dispersed residence and new centralized villages. The foreignness of living together is reflected in the fact that all Korowai terms for "village" are borrowings from the intrusive lingua franca of Indonesian, such as the word xampung (borrowed from kampung). Cities or "big villages" (xampung-tale) are envisioned as larger versions of the twenty villages now existing on Korowai people's own land, while the villages are understood as 
small local versions of real cities. "Village" and "big village" (or "city") together contrast with "forest" (du-lebul), the ongoing space of old-style dispersed living on clan territories. This understanding that "village" and "city" are not opposites but intensities of a single pole is one way Korowai ideas diverge from city dwellers' models.

Regular interactions between Korowai and long-distance strangers began in 1978, when Dutch missionaries and Papuan assistants established a post on the southwest edge of their five hundred square miles of land. Many further strangers have since visited, including Indonesian or Papuan government officials, Indonesian traders, Western tourists and filmmakers, and Indonesian or Papuan tour guides (Stasch 2014b). Through interaction with these people, specific towns in Papua have become widely discussed in Korowai speech. Through these same connections as well as at their own initiative, Korowai have traveled in increasing numbers to towns for commerce, schooling, healthcare, government or church training, and adventure. Out of roughly four thousand Korowai, perhaps one in five persons has visited a regional administrative center such as Senggo or Tanah Merah, and one in fifteen has visited a major coastal town such as Merauke or Jayapura. A dozen men have visited large metropolises like Jakarta or Medan, lying two or three thousand miles to the west.

Yet while Korowai have many connections with cities, their main relation to them is combined mental involvement and experiential separation. To reach the nearest towns takes several days of walking or a costly motorized canoe trip. Reaching larger cities such as Wamena, Merauke, and Jayapura involves airplane or ship connections that are beyond most people's means. Even for the fraction of persons who have actually been to a city, the trip was an exceptional life event. 
Verbal accounts of cities often circulate energetically, at a remove from firsthand experience. For twenty years, it has been normal for shamans to visit cities during nighttime séances, for all persons to see cities in dreams, and for individuals to report shocking nighttime experiences of entering a local grave and seeing a city there. In 2011 a spirit medium who had never visited a town in waking life described to me two nighttime trips he made to Singapore, where he poignantly reunited with his dead parents (compare Kempf 1999:108). These forms of relating vividly to urban space through occult channels are a variation on more prosaic daily talk about cities as rumored spaces beyond direct experience.

"Villages" are an important proxy through which people also experience cities' combined closeness and distance. The villages that Korowai have actively formed across recent decades continue to be culturally bizarre to many persons, because of their visual openness, social crowding, cash economy, and association with Indonesian speech (Stasch 2013). However, villages are so widespread on the land that almost everyone has had direct experience of them. This gives people a basis for extrapolating what cities must be like, making the idea of cities vivid. Yet feelings of cities' distance, impossible scale, and unfamiliarity are also deepened through direct experience of villages, because cities are discussed as far exceeding local villages in size and other strange characteristics.

\section{Knowing Otherness of People by Otherness of Space}

Writing about interethnic relations in Amazonian Peru and Ecuador, Taylor (2007) states that the ethnic taxonomy of "wild Indian," "tame Indian," and "White" focuses not on skin color or other fixed attributes but on activities, within a regional system of different modes of life. To be a "wild Indian" is to be 
embedded in a web of kinship, inhabiting the interfluvial "deep" forest..., to repel relations with outsiders, and to live on forest produce without producing wealth. Being a "tame" Indian...is to domesticate this wildness by initiating its transformation into money and proper sociality, and to inhabit the loci-rivers and, increasingly, roads - that articulate forest and city spaces. Being "white," finally, is to be "urban," at a remove from the forest and its inhabitants, in a world where relations, including kinship, are entirely monetarized (137-138; see also 136).

For Korowai, cities are similarly a figure of anthropological difference. The city as exotic space is also an exotic type of people and an exotic logic of society.

The anthropological other with whom Korowai prototypically associate cities is a lexical category I gloss as "Foreigner," capitalized to indicate that it is used as the name of an ethnic collectivity, paralleling use of other Korowailanguage ethnonyms. The Korowai word for "Foreigner" is laleo, and it could also be glossed as “Demon," "Zombie," or "Walking Corpse.” Its historically and semantically primary denotation is a terrifying monster humans become after death. In this "Demon" sense, laleo constantly occurs in discourse as an antonym of words for "Human." In early interactions with missionaries, tourists, Indonesian traders, and nonlocal Papuans, Korowai fully identified the new outsiders with after-death monsters. But now the fact that a single word means both "Foreigner" and "Demon" is increasingly a matter of wry ambiguity and frozen idiom, not full semantic unity. However, the "Foreigner" and "Demon" categories continue to have in common that they are each imagined as an antithesis to normal humanity. 
In the rise of cities as a figure of anthropological difference, this spatial form has likewise been constructed as an antithesis to the home Korowai landscape (compare Thomas 2002:376).

In current Korowai stereotypy, Foreigners' attribute of living in cities is a main focus of their otherness, and there are many specific features of urban space that stand out as strange. Korowai are awed by the idea of closely-spaced dwellings made of concrete and metal, and by differences of bodily activity and skill accompanying this material otherness. When some Korowai and I were watching German tourists negotiate the crisscrossed logs of a garden clearing, one youth connected the awkward scene to the tourists' rumored home conditions. He burst out in astonishment: "They just stay in the house. They only go by car, they only go by motorcycle, they can't walk!" (xaimantanux, mobiltanux, ojektanux, wolaxolol brxaundinda). But the most prominent stereotype about cities centers on moneymediated provisioning. Korowai describe the urban order in terms of Foreigners' food and other articles being "just there." As one man put it, "They are the people who stay eating what just exists" (ibo xondüp iboləxa lexaməteanop). By this he meant that city dwellers live in their houses atop piles of food and money that are not diminished by consumption (compare, for example, Pigg 1992:507-508; Gow 1993:332, 335). Korowai contrast this with their own forest situation of needing to descend from their houses and work strenuously to get food.

These various categories and associations quickly raise many questions of whether exoticizing statements are literal or figurative in character, and how exoticizing stereotypes are affected by practical experience of foreigners, their spaces, and their institutions that is more complex than what the stereotypes portray (but see Bashkow 2006:53-57, 87-89, 206-207, 246, 282n30). Adequately 
addressing these questions would require a lengthy discussion I cannot afford here, having chosen to focus on the complexity and liveliness of the stereotypy itself. However, I do want to touch momentarily on a few issues surrounding stereotypes' experiential basis and practical application, to suggest that stereotypy can actually gain force from complexity of empirical correlations. For example, the utopian image of city dwellers as living on piles of articles gets support from direct Korowai experiences, as well as from hyperbolic contrast with Korowai people's own conditions that is fantasized at a remove from direct experience. Tourists eat food prepared by a cook, and the food comes out of baggage in physical forms that appear just to exist, rather than bearing a history of production from the landscape (Bashkow 2006:145-208). Korowai also marvel at the sheer quantity of tourists' visible articles, food, and money. Visiting town, Korowai see extraordinary accumulations of objects in shops and households. Even persons who have never visited towns or met a tourist may have the experience of eating imported rice and instant noodles brought by a relative to a forest house. The unusual taste of the food mingles with its novelty of being procured in ready-to-eat form, by purchase rather than labor. Stereotypy of cities as spaces of consuming what is "just there" can be an extrapolation from such distant brushes with the market order, such as eating a packet of noodles.

Parallel points apply concerning who is a "Foreigner," and what their relation is to monstrous "Demons." Part of the stereotypy-supporting effectiveness of the word laleo in its "Foreigner" sense is its semantic fluidity (compare Thomas 2002:375; Bashkow 2006:121-122, 225-226; Keller 2015:79-112, 194, 203). In most uses, all radical strangers are lumped under it, including White or East Asian missionaries, tourists, filmmakers, and scientists; Indonesian government workers, 
traders, or tour guides; and Papuan church workers, schoolteachers, tour guides, or government officials. There are also usages in which Whites are clearly its prototype. And there are new categories that entirely replace the catch-all category of "Foreigner" with a more differentiated ethnic taxonomy. Yet like stereotypy about "cities," stereotypy about "Foreigners" circulates prolifically beyond contexts where strangers are actually present, or where people care about differences among them. The category "Foreigner" centers semantically not on a stable appearance or other essence, but strangers' polymorphous otherness to Korowai on all levels of embodied culture.

I already noted that Korowai at first fully assimilated long-distance strangers to laleo in the "Demon" sense, but have later increasingly differentiated "Foreigner" from "Demon" as a new sense of laleo, understood to be human rather than dead. Against this tendency, in talk about cities Korowai are reambiguating the relation between the old dead and the new strangers, in ways that suggest that the popular notion of "literal" versus non-literal use of words is not ultimately helpful to understanding monster categories' application to human strangers. As I will address more below, cities are thought of as inhabited by the dead as corpselike "Demons" or laleo. Yet cities are also closely identified with Indonesian, Papuan, and White "Foreigners," also laleo, whom Korowai routinely meet directly and recognize as "human." Thinking of death as travel to a city might seem to follow syllogistically from identifying new strangers with the demonic dead in the first place, and knowing that cities are the strangers' characteristic living space. But the discourse of death as travel to cities has arisen later than the initial time of bluntly categorizing strangers as monstrous Demons and first hearing about cities. It has occurred when instead the strangers are losing their nonhuman aura, and 
Korowai are visiting cities themselves. The contradictoriness of these patterns is partly softened by the fact that the monster category laleo was "ethnic" to begin with, and there was continuity between intrahuman and extrahuman social relations. This ethnic character of the after-death "Demon" population was reflected in the idea that the dead had a proper "Demon territory" far downriver from the Korowai area, analogous to the owned territories of Korowai and their ethnolinguistic neighbors. New expressions for the city of the dead, including "big village" or "Demon village," are often used as interchangeable synonyms with the earlier category "Demon territory" (laleo-bolüp) describing the land of the dead. Yet I suggest that the prior ethnoterritorial coloring of "Demon" is itself typical of a wider pattern in which the monster term's semantic content is one and the same with its complex epistemological and social conditions of application by speakers, as an all-purpose resource for interaction with that which is alien (see also Stasch 2014a:204-210). In other words, like other monster figures cross-culturally, this one is a category having the paradoxical semantic meaning, "that which defies categorization (even in the midst of our involvement with it)." As an all-purpose resource for dealing with what is alien, laleo is routinely used in ways that simultaneously affirm the term's prototypic imagery and adapt the term experimentally to fluid empirical situations.

\section{Hierarchy of Places as Hierarchy of Human Worth}

Having outlined how the city as a space stands for "Foreigners" as an ethnicity of people and for an economic and moral system, I now add to this semiotic network the point that the city is metonymic of a hierarchy of spaces, which is a social hierarchy. New rural-urban articulations are also structures of 
inequality. Some stereotyped attributes of cities and Foreigners are repulsive, or evaluated negatively. But when Korowai voice stereotypes of urban consumer wealth, this increasingly entails feelings of desire and self-deprecation.

One pattern illustrating this point is many Korowai speakers' now oftenexpressed wishes for local villages to become "big" (xongel, baul). The statements refer to physical expanse, population, and scale of commerce. Disparaging local villages as "small," Korowai ignore the ethnic domination characteristic of town growth throughout the rest of Papua, where immigrant Indonesians control commercial life. They want to unite their existing position as local landowners with a position of superiority in the new economic system.

This wish for "big villages" coexists with many further expressions of desire to become "like Foreigners" or "like village people" (laleo-alin-ülop, xampung-anop-ülop), such as by gaining access to imported consumer goods and the moral and bodily habitus linked with them. To live like a Foreigner would be to buy ready-to-eat foods, cook with pans and oil, wear clothes, and wash with soap. Other practices sometimes explained as motivated by desire to live "like Foreigners" include speaking Indonesian, moving from forest to village, or adopting a new political and religious ethos of renouncing anger and living together harmoniously (Stasch 2013; 2015:82). ${ }^{5}$

Another practice exemplifying new consciousness of interethnic hierarchy is the sending of boys to towns for schooling in the hope that they will gain fluency in Indonesian and become schoolteachers, civil servants, police, or elected officials (compare Weber 1976:328; Pigg 1992:502, 511). Here too cities figure as a characteristic space of Foreigners metonymic of an entire alternative organization of life. Two villages in the Korowai area have primary schools, but teachers are 
rarely present, and anyone outside them or wishing to attend higher grade levels must migrate, at great hardship to themselves and their families. About fifty youths are attending school in towns between twenty-five and two hundred miles away. Relatives expect the boys will later return to share wealth with those who supported their schooling. Korowai refer to hoped acquisition of a salaried job as "becoming human" (yanop-telo), entailing both the status-celebrating meaning of the English "become somebody," and the self-deprecatory implication of being less than human without such a job. The expression is a loan translation of an Indonesian phrase also meaning "become human" (menjadi manusia), widely used by Papuans in this region to refer to getting a civil servant job, influenced by successive Dutch and Indonesian colonizers' categorization of traditional Papuan life as uncivilized. I have argued elsewhere, though, that desire for Foreigner culture has been shaped not only by colonizers' structures, but also by preexisting Korowai sensibilities about social inequality in relations among themselves, including use of selflowering as a positive way to elicit care (Stasch 2015b; compare Fausto 2013:171172). In a fuller account, patterns of self-deprecation would additionally need to be set alongside ongoing Korowai assertions of their standing as landowners, and of the superiority of their heritage moral norms and embodied cultural skills. But whether following Foreigners' judgments or their own reasoning, numerous Korowai now desire the foreign order and its wealth. Entry into knowledge of cities has been entry into a vision of themselves as occupying subordinate positions within global hierarchies of worth (compare Robbins and Wardlow 2005; Bashkow 2006; Robbins 2008).

In this way, urban space is a mediation of something else: a structure of interethnic hierarchy in which Korowai have an inferior place. Korowai thinking 
about cities converges with views of Marxist geographers in the tradition of Lefebvre (1991), in refusing to fetishize space as an inert container separable from its animating social conditions. There is a certain clearsightedness to their identification of city space with money-mediated consumption of vast accumulations of preexisting goods, a bizarre alternative economic order casting a shadow of inferiority across those without access to it.

\section{Cities of the Dead: Deprivation as a Unity of Conflicting Emotions}

These patterns of the city working as a figure of anthropological otherness and of a structure of hierarchy, striving, and deprivation are important to understanding why Korowai link cities with death. In analyzing imagery of the urban dead now, though, I will add to these levels a concern with the ambivalent psychological structure of loss, desire, and loss-crossing connection entailed in experiences of deprivation and striving under the new hierarchies.

The element of otherness alone takes us some distance in understanding cities' association with dying. When people reckon with outlandish new actors and institutions, it might make sense that they would turn to the dead for help, if these dead are already paradigmatic of social relations combining involvement and otherness.

Many details of Korowai imagery of the urban dead do center on otherness. When Korowai experience visionary travel to cities where the dead go, what they see is an urban population of laleo in the original sense of nonhuman monsters. Someone who describes a dying person as "going to the big village" is usually talking about the person's future as a Demon, not some other element of personhood (as is also implied in routine use of laleo-xampung or "Demon village" 
as one name of the destination). Demons have long been stereotyped as inarticulate, stiff with rigor mortis, and having rotten flesh that slides off their bones, imagery reinforcing people's sense of city space as a radically strange periphery. Linking cities with the dead underlines how startling the idea of urban space is to Korowai. City norms are so beyond received experience that people connect the urban to a fundamentally different category of being. This is typical of a wider pattern of making death relevant to all kinds of interpretive needs in life (compare Stasch 2009:208-209). For example, another reason death is helpful for thinking about cities concerns demographic scale. Some Korowai have reasoned to me that the largeness of urban populations reflects the huge quantity of people who have died, dwarfing the population of the living (compare Calvino 1974:95). Death's cumulative traumatic weight makes it an apt figure for the new otherness of mass society.

Attention now fixed on "Singapore" probably follows from basic definition of the city of the dead as a periphery of generic otherness. Singapore lies two thousand five hundred miles away, and there are no specific practical connections between Korowai and Singapore that explain this city's popularity in death talk. The pattern seems to have followed from Singapore being regionally prominent enough that visiting outsiders or neighboring Papuans have spoken this city's name with some frequency, while also being outside the ambit of domestic Indonesian cities that Korowai hear about directly from people who visit or live in them. Like names of closer cities that entered Korowai speech in the 1980s and 1990s, the novel name Sinapol holds considerable aesthetic fascination. It is a concrete phonological form understood to refer to a specific place, but it is also unfamiliar in sound, mirroring the city's inaccessible physical and perceptual distance. As the 
land of the dead, Singapore is also frequently referred to by the Indonesianlanguage epithet "Worm City" (kota cacing). Even Korowai who do not speak Indonesian know this alternative name and its semantics. The name evokes fascinated repulsion, because Korowai take worms as the paradigm of disgust, and link them with graves (Stasch 2008:8, 15). Persons who travel to Singapore in nighttime visions recount details such as that rice there is red instead of white. Rice is a Foreigner-marked food that Korowai now greatly prize, but red rice raises the food's uncanniness to a shockingly greater extreme. These motifs of deformity are ways Korowai further play up cities' otherness, even while the otherness of cities plays up the unassimilability of death. When dying persons say they are going to Singapore, their relatives usually experience this as a shock. The city's exotic strangeness amplifies the alienness of the idea of the person permanently disappearing from their lives.

This quality of otherness intertwines with qualities of domination and temporal rupture, in motivating cities' association with death. We might reason prima facie that death is a basic experience of being determined by forces outside one's control, such that linking the new political economy to the dead is a good way to make sense of the hierarchical aspect of that system, and the inaccessibility of its positions of privilege. Perhaps being dominated by markets, states, and other city-anchored institutions feels like death, such that death is a good name for the urban. So too, if social life centrally involves inheritance from past others of many presupposed conventions and conditions, a rupture in basic world order might reasonably prompt people to look to the dead as figures connected to that historical break. 
The actual ethnographic details I can provide illustrating that cities' links to domination and rupture are what motivate their connection to the dead take us into the lived subjectivity of deprivation accompanying sudden entry into this structure of domination. Past identification of the dead with a downstream ethnic territory and their new identification with cities might seem fancifully exotic, but they unfold within a broader pattern of everyday spatialization of emotion. Place and geographic separateness are for Korowai focal media of pleasure in being together, and of grief over separation. For example, Korowai relate to a specific death by coresidents moving away from the house where it occurred, and by relatives from elsewhere demanding material valuables from the house residents (Stasch 2009:217, 233-241). The idea of a city of the dead likewise puts a geographic face on death, through which bereaved persons imagine lost relatives as still existing somewhere, or even imagine reuniting with them through occult travel. One man, after recounting to me how his dying brother-in-law had said "I'm going to Jayapura," went on to ask "And so perhaps you have not seen him?" (amodo gu bimbodabəne), since I had arrived via Jayapura. But more illuminating was his next statement, recalling his intense grief: "I thought, 'We should have gone together, like when people go to a feast out in the open"' (damtaxfosï xo gil xaimatelaxaülop, nохи amomdo lelip aigilfafonхup dəle). Instead, the brother-inlaw had "left by stealth" or "left invisibly."

Walking to a feast with relatives as a troupe of singers is a prototypic act of travel, and people regularly contrast this image with separation by death. My interviewee's reasoning turned on the contrast between shared travel across the landscape by many people "out in the open” (damtax), and a dying person's disappearance from others' lives by travel that is "stealthy" or "invisible" (nanem). 
This contrast suggests that Korowai understand not only place but also travel across places as fundamental to social relations. Traveling together to visit others epitomizes shared life, while if someone is socially absent then there is a geographic reason: they have traveled elsewhere. Under conditions of residential dispersion, everyday Korowai affairs are dominated by longing for relatives who have gone elsewhere, and by travel to affirm bonds across separation. These patterns are strong enough that the idea of a person disappearing in a nongeographic manner makes little sense. If someone is absent more profoundly than being a couple days' walk away, Korowai still understand the person as being some place. They seek to imagine what place is so foreign that the living have no access to it.

What people mainly express when they speak of "going to the big village" is grief surrounding separation of survivors from the dead or dying. Statements about someone "going to Jayapura" or "going to Singapore" express desire not to be separated, and pain of no longer being together. Newly rumored cities are powerful images of the breach between survivor and deceased, because of their fantastic alienness in physical distance and social principles. Conversely, linking cities and the demonic dead is a way Korowai understand their own condition of basic separateness from mass consumption, and erratic access to fragments of it. Space is for Korowai regularly a medium of conflicted subjectivities of both social connection and loss or desire. These patterns take particularly sharp forms in contexts of death. Talking about death is talking about being dominated by loss and desire, while also remembering conditions of being together or imagining what it would be like to not be in grief. Pain about a relative's death or one's own death is an apt model for the relation of simultaneous deep mental involvement and 
exclusion that Korowai now have with the urban market order. The combined fearful shockingness and attractiveness of cities parallels the combined extreme absorption and difficulty of relations with death.

The linking of the dead and urban wealth that I have been discussing bears similarities to a wider pattern of reasoning in Melanesian societies connecting white colonizers' economic wealth with the ancestral dead. This pattern is often understood by observers as a quintessential "cargo" belief. Stephen Leavitt, in a series of insightful publications about this linking of white wealth and dead ancestors about Bumbita Arapesh of PNG, has documented that for Arapesh the main focus of these ideas about desired foreign wealth was the pained moral quality of bonds with specific deceased relatives (e.g. Leavitt 1995; 2004). He found that "cargo beliefs can offer a compelling cultural frame for working through residual feelings over the deaths of parental figures" (1995:454). What I am suggesting is a reverse point, that Korowai feelings over the deaths of parents and other kin offer a compelling frame for working through difficult emotions of hope, grief, and deprivation in relation to cities, mass consumption, and the alternative economic order of urban life. While the image of "going to the big village" is mainly a way Korowai speakers express grief about separation, my acquaintances also occasionally explain these statements as sequiturs to the dying person's unrealized desire to visit a city when alive. One pattern in Korowai egalitarianism is for a person who lacks an object or experience to feel admiration, desire, and painful inferiority relative to others who possess it. Most Korowai have relatives who have visited towns, and everyone has heard about tourists and other Foreigners known to live in cities. Desiring the experience of urban travel is a common response to this knowledge that others have been to those places. Many persons 
feel intense longing to see the alien cities they have heard about, while also describing such visits as fearful and unattainable. Lack of access to cities in waking life lends appeal to the idea that the dead go there.

The present is a time of volatile instability in Korowai views about their position in a wider geography. In their routine engagements with mortality, Korowai are accustomed to much this same kind of emotional and evaluative volatility. Even the imagery of "Demons" involves an ambivalent subjectivity of both fear and desire. Repulsion toward these horrifying monsters can mingle with attraction to being reunited with lost relatives (Stasch 2009:215-223). For example, there are many myths in which a recently-deceased Demon and its living spouse are reunited, and they try to live together in the same house, a situation listeners find very poignant (ibid., p. 219-220). This redemptive dimension of the repulsive "Demon" is expanding in contemporary thought about cities. For example, full conflation of desires in relation to the inaccessible dead and the inaccessible privilege of cities occurred in a widespread interpretation of rural aid payments received by families in certain villages around 2007. ${ }^{6}$ These windfalls of US $\$ 100$ per married couple were retrieved from distant administrative seats by village officeholders. Recipients spent the money on clothing, steel tools, rice, instant noodles, tobacco, and other imports. The main rumor by which Korowai interpreted the money was that it had been sent by deceased family members, who were eating limitless rice and noodles in their place, and who felt longing for their living relatives who lacked food. One man told me in 2007:

We think, "Our elder brothers and younger brothers, our mothers and fathers who have died, their Demons say 'Take this money,' out of 
sorrowful longing [finop] for us." They think, "Aüüüaaa, we died and our rice and noodles, our food, is not little in quantity. There's a fount of plenty and so we eat. We have a fount of plenty. Aüüüaaa, our children, our elder brothers and younger brothers, they have no food," and they send that money for us. We live empty-handed. They say, "They have to search laboriously for food, while we eat what's just already there," and they put money for us.

The idea of Demons giving food to their living relatives out of love is not new. Korowai have a word meaning "lethal food gifts from the demonic dead" (lumbel, see Stasch 2009:219). This idea is important background to the rumors about government aid, but in this new representation, receiving gifts from the dead is positive rather than terrifying. Against the background of outsiders sensationalizing Melanesian hopes of receiving inaccessible imported wealth from dead ancestors as "cargo" thinking, what seems most significant about the Korowai representations is again that they put a kinship face on the order of Foreigner superiority. Like sending boys to town for schooling, hopes about gifts from the urban dead envision cross-generational kin relatedness as a path to overcoming disenfranchisement in the new ethnic hierarchy.

\section{The Dead and Historical Rupture}

The complexity of bereavement is also a time-focused emotional structure. In the imagery of death as travel to a city, the unity of contradictory emotions in relation to urban power is also a unity of contradictory emotions in relation to the newness of that order. 
In Taylor's essay about western Amazonia that I already quoted, she further writes that "illness is [Shuar people's] major mode of conceptualizing interethnic history, because it is a striking experience of painful temporality and because it involves the perception of a negative alteration of the web of relations underlying selfhood" (Taylor 2007:15). Korowai follow a parallel logic in making death central to their historical consciousness of entering new large-scale structures of interethnic articulation. In many contexts, death is for them prototypic of what it is for something to happen. Narrating life histories, Korowai foreground deaths as the defining events of extended biographic periods. Bereavement observances involve mourners being reflexive about their own temporal process of passing between one condition of attachment and another (Stasch 2009:223-233). Death is also prominent in thought about collective time. Korowai previously had a concern that the world could end by the demonic dead bursting out en masse among the living. This played into people's profound fear when missionaries and other radical strangers first intruded, and this status of the dead as a horizon of collective time has probably also contributed to connecting death and cities. I describe elsewhere how Korowai divide their history into an epoch "without villages" and an epoch "after villages were opened" (Stasch 2013). We have seen here that cities are likewise seized on as defining centers of the historical order Korowai now live in, metonymic of mass consumption and the Foreigner ethnicity. If the advent of the dead was already "history" in the sense of an anticipated apocalyptic change, it further makes sense that the dead and cities would be linked.

I suggest that just as a position of subordination and deprivation reverberates through subjectivity as a unity of contradictory emotions, so too standing in relation to radical change is psychically contradictory. Yet the 
preexisting image of the monstrous dead pouring forth onto the land can be read as an idea that a temporality of interruption latently underlies the home landscape and is not confined to the spatial periphery. The ubiquitous Korowai spatialization of emotion and emotionalization of space that I outlined above also amounts to an openness toward transition from one condition to another, as an everyday social quality (compare e.g. McDowell 1988). Mourning practice and all other ways people conceptualize and relate to death events are again an especially strong case of contradictory structures of subjectivity, that are also structures of transformation. Any cognition in relation to death is a multitemporal condition of both disruptive change and ameliorative adjustment-to-change, with all sorts of evaluative feelings such as fear, longing, attachment, or deprivation accruing simultaneously to the different times present in that moment (cf. Stasch 2009: 228, 270). The new understanding of death as travel to Singapore is one condensed form given to the volatile unity of conflicting subjective qualities Korowai feel in relation to Foreigners' social order, both with respect to its hierarchical subordination of them and with respect to its newness in time.

\section{Conclusion: Body, Land, and Cognitive Engagement across Normative Systems}

I have sought to show how a spatial form's vivid force as a site of their historical consciousness can flow from the way it works for people as a figure of multiple elements of their overall world, drawing them together in one unitary idea. Within this, I have further illustrated how a spatial form can importantly mediate a systematically contradictory emotional and evaluative experience of a historical situation. I organized my development of these points partly around the puzzle of 
Korowai describing death as travel to a city. This is an ethnographic object "in motion": the pattern of talk was innovated and rose to popularity just in the last fifteen years, and it may be abandoned in coming years as Korowai people's conditions of living further shift. Yet I have drawn on this fluid historical object's richness of imagery to trace analytic themes of broader comparative relevance. Addressing why Korowai take death as a good figure of the anthropological difference and ethnic hierarchies associated with the new spatial form of the city involves addressing a question of a system of subordination to urban others feels like, for those participating in it anew. My answers to these questions have centered on the contradictoriness of the relation Korowai have with all cities are associated with, a contradictoriness harmonizing with complexly fractured subjectivities surrounding death. The idea of death as travel to a city gives voice to the contradictory structure of feeling Korowai occupy in their present historical situation, systematically joining plural emotions.

It is in the character of the kinds of relational processes dealt with here that the interpretations I have put forward cannot be expected to apply (or to be irrelevant) in an absolute way across human social settings, or to be a full account of a single case. Rather, the model's possible value lies in how it might help us draw into greater visibility certain partial but recurrent patterns, and make sense of them. Processes of people making a spatial form a focus of their broader historical consciousness, or experiencing structural contradictions of history through contradictory feelings in relation to a spatial form, seem to recur a great deal in the comparative ethnographic record, and hopefully my exploration of main associations that cities carry for Korowai (including associations with the dead) has 
thrown such processes into further relief as important subjects of comparative attention.

I would like to close with one schematic idea that goes beyond the aboverepeated main points, by asking why spatial forms have such power in the thinking of history. Why does geographic thought work as such a focal domain through which actors conceptualize their larger conditions of living in hierarchical structures of unequal worth?

One important answer is that Korowai, like some other people, are exceptionally geography-centered in their modes of conceptualizing social process generally (see also Stasch 2009; 2013). In thinking new histories by thinking the city, they are elaborating this same earlier sensibility under new conditions. A second answer is the geography-centered character of the institutions Korowai are now engaged with. Cities are important in historical consciousness because they are the actual homes of the new wealthy, powerful actors Korowai meet. Concrete travel up a hierarchy of population centers has been a main context of Korowai coming to know the new institutional orders. Korowai form an idea of "tourists" as an ethnic type (tulis, for many people also the prototype and synonym of laleo "Foreigner") by witnessing the local culmination of their travel. This pervasively geographic grounding of the new interethnic hierarchy supports city space's rise as a synoptic image of the overall structure.

But to these kinds of answers, which could be valuably dwelt on at more length, I want to add the further tentative suggestion that part of the power of spatial forms as sites of historical consciousness flows also from the poetics of a spatial landscape as a kind of second body, in complex relations to people's first bodies. This idea of land as a second body is something I previously forwarded in 
trying to understand Korowai ideas of territory ownership, including how deeply their local social interactions are crosscut by different people's feelings of belonging or alienness in relation to specific portions of the landscape (Stasch 2009:25-72, especially p. 29). Here I would like to adapt the metaphor to a different level of problem.

Often a landscape reflects and incarnates a culturally and historically relative normative system (e.g. Basso 1996), or a structure of clashing systems and values. Interacting with a landscape, people may experience certain normative assumptions of life to be as given as the spatial field itself, or they may experience normative arrangements to be as contingent and changeable as certain features of the land. In many contexts of Korowai people's activity on their own regional landscape, there is a degree of harmony between the category systems and normative frameworks sedimented in their corporeal feelings and skills at the level of their first bodies, and the category systems and normative frameworks they see and feel while engaging with the geographic landscape. Going to a city, or imagining such a trip, is by degrees more of an experience of gaps between embodied normativities and normativities made present by a spatial surrounding. And yet in being a spatial form, the city has qualities of being somewhere, and so theoretically visitable and part of one's world, as well as being difficult to reach or relate to. People can practically or imaginatively put their first bodies in relation to an alien landform, by moving across it or by conceiving an embodied subjectivitity that would be in harmony with that space. Focusing on a spatial form as the main sign of a new historical system is a powerful path by which to hold that historical system in a middle zone of cognitive assimilation and recognized social involvement, on the one hand, and externality and distance, on the other hand. This 
line of inquiry would be valuable to pursue, in a more extensive exploration of the ethnographic issues I have addressed here.

\section{Notes}

I owe much to the patience, candor, and thoughtfulness of several hundred Korowai who have related experiences of history and mourning to me between 1995 and 2011. Equally generous were audience members who made suggestions in response to earlier drafts presented at SOAS, UCL, Manchester, Museu Nacional/UFRJ, the London Melanesia Research Seminar, and a workshop of my and Joel Robbins' students at UCSD. For hospitality at these times, or guidance at other important points, I am grateful to Lissant Bolton, Matt Candea, Jenny Chio, Carlos Fausto, Paolo Heywood, Naomi Leite, Stephen Leonard, David Parkin, Alexandra Pillen, Joel Robbins, Michael Scott, Karen Sykes, Soumhya Venkatesan, Aparecida Vilaça, Michael Chibnik, and four American Anthropologist reviewers. I regret only being able to address here a small portion of the insightful comments different people have offered in relation to my discussions.

\footnotetext{
${ }^{1}$ In the same breath, though, he emphasized that this great prominence of "ideas and images of country and city," as a focus of social and historical consciousness is "matched only by the fact of the great actual variation, social and historical, of the ideas themselves" (ibid.). His book is a sustained argument against conceiving city, country, and the relation between them as transhistorical universals.
}

${ }^{2}$ A brief comment on my use of the word figure may be in order. I wish to focus my analysis on the topic of spatial mediations of historical consciousness, so I will 
not be commenting extensively on the nature of processes of representation in general. One basic thing I am seeking to do, though, is to model an analysis that does not accept a separation between people's experience of cities (or other spatial forms) as physical entities with causal effects on their lives and their experience of cities as profoundly relational and imaginative entities that make present more than themselves. In the absence of a lengthy discussion of this theoretical issue and relevant literature (but see Stasch 2003, 2014b), for present purposes I find figure to be a useful noun for discussing what cities are to Korowai. This is because the term joins the meaning "a person, thing, or action representative of another" (Merriam-Webster's Collegiate Dictionary, 11th edition), with several other senses designating an entity that is physically and historically real but emphasizing that entity's "shape," its "form," or its quality of being more than itself: for example, "an object noticeable only as a shape or form, (figures moving in the dust) ... appearance made; impression produced (the couple cut quite a figure) ... a prominent personality (great figures of history)." Additionally, in "figure of speech" and similar uses, the term carries the sense of a deviation from more normal semantic usage bearing artful force because of its unexpected but also intelligible character. This also has affinities with the associations carried by cities for Korowai that I will discuss. If preferred, words such as sign, symbol, representation, or mediation could be mentally substituted wherever I use figure, but keeping in view the points outlined in this note.

${ }^{3}$ The statements, as recounted to me by relatives of the dying persons who uttered them, were: nu Wamena xaimbale; xampungtale xaimbale, jajapula xaimbale; and u nəmbaməni nu gəyaxtimbale, nu nəxampungtale loxtəlep. 
${ }^{4}$ Throughout the publications by Kempf and Hermann I have cited, they also give full citations of many further cases in PNG-focused literature of people linking cities and the dead, that I have not listed.

${ }^{5}$ The first main Korowai understanding of Christian religious affiliation has been that it consists of renouncing "anger" or "violence," in favor of living together peaceably. Alignment with this broad idea has emerged much earlier and more widely than knowledge of biblical narratives or ritual participation in congregations (which was very limited until about 2010). In a possibly anomalous difference from patterns elsewhere in New Guinea, Korowai linking of cities and the dead has not been significantly influenced by the rich imagery of cities in Christian doctrine, having arisen initially among networks of speakers wholly unaware of that imagery.

${ }^{6}$ The funds originated from a provincial government program formally called the “Strategic Village Development Plan" (Ind. Rencana Strategis Pembangunan Kampung), often shortened to "Respect" (Respek). For context, see for example Nolan, Jones, and Solahudin (2014). 


\section{References Cited:}

Bashkow, Ira

2006 The Meaning of Whitemen: Race and Modernity in the Orokaiva Cultural World. Chicago: University of Chicago Press.

Basso, Keith

1996 Wisdom Sits in Places: Landscape and Language Among the Western Apache. Albuquerque: University of New Mexico Press.

Calvino, Italo

1974 Invisible Cities. New York: Harcourt Brace \& Company.

Ching, Barbara, and Gerald W Creed, eds.

1997 Knowing your place: Rural identity and cultural hierarchy. New York: Routledge. Fausto, Carlos

2013 Feeding and being fed: reply to Walker. Journal of the Royal Anthropological Institute 19(1):170-178.

Gow, Peter

1993 Gringos and Wild Indians: Images of History in Western Amazonian Cultures. L'Homme 33(126):327-347.

Herzfeld, Michael

1991 A Place in History: Social and Monumental Time in a Cretan Town. Princeton: Princeton University Press.

Keller, Eva

2015 Beyond the Lens of Conservation: Malagasy and Swiss Imaginations of One Another. Oxford: Berghahn. 
Kempf, Wolfgang

1999 Cosmologies, Cities, and Cultural Constructions of Space: Oceanic Enlargements of the World. Pacific Studies 22(2):97-114.

2008 Mobility, Modernisation and Agency: The Life Story of John Kikang from Papua New Guinea. In Telling Pacific Lives: Prisms of Process. B.V. Lal and V. Luker, eds. Pp. 51-67. Canberra: ANU E Press.

Kempf, Wolfgang, and Elfriede Hermann

2003 Dreamscapes: Transcending the Local in Initiation Rites among the Ngaing of Papua New Guinea. In Dream Travelers: Sleep Experiences and Culture in the Western Pacific. Roger Lohmann, ed. Pp. 61-85. New York: Palgrave Macmillan. Kildea, Gary, and Andrea Simon

2005 Koriam's Law, and the Dead Who Govern. 110 min. Canberra: ANU Research School of Pacific and Asian Studies Film Unit.

Kohn, Eduardo

2007 Animal masters and the ecological embedding of history among the Ávila Runa of Ecuador. In Time and memory in indigenous Amazonia: anthropological perspectives. Carlos Fausto and Michael Heckenberger, eds. Pp. 106-129. Gainesville, FL: University of Florida Press.

2013 How forests think: Toward an anthropology beyond the human. Berkeley: University of California Press.

Lattas, Andrew

2006 The utopian promise of government. Journal of the Royal Anthropological Institute 12(1):129-150. 
Leavitt, Stephen C

1995 Seeking Gifts from the Dead: Long-Term Mourning in a Bumbita Arapesh Cargo Narrative. Ethos 23(4):453-473.

2004 From "Cult" to religious conviction: the case for making cargo personal. In Cargo, Cult, and Culture Critique. Holger Jebens, ed. Pp. 170-186. Honolulu: University of Hawai'i Press.

Lefebvre, Henri

1991 The Production of Space. Oxford: Blackwell.

McDowell, Nancy

1988 A Note on Cargo Cults and Cultural Constructions of Change. Pacific Studies 11(2):121-134.

Munn, Nancy D

2013[2004] The "becoming-past" of places: Spacetime and memory in nineteenthcentury, pre-Civil War New York. HAU: Journal of Ethnographic Theory 3(2):359-80.

Nandy, Ashis

2007 An Ambiguous Journey To The City: The Village And Other Odd Ruins Of The Self In The Indian Imagination. New Delhi: Oxford University Press.

Nolan, Cillian, Sidney Jones, and Solahudin

2014 The Political Impact of Carving Up Papua. In Regional Dynamics in a Decentralized Indonesia. Hal Hill, ed. Pp. 409-432. Singapore: Institute of Southeast Asian Studies.

Nordenskiöld, Erland, and Ruben Perez Kantule 
1938 An historical and ethnological survey of the Cuna indians. Göteborg: Göteborgs Etnografiska Museet.

Pandian, Anand

2009 Crooked Stalks: Cultivating Virtue in South India. Cambridge: Cambridge University Press.

Pigg, Stacy

1992 Inventing Social Categories Through Place: Social Representations and Development in Nepal. Comparative Studies in Society and History 34(3):491-513. Robbins, Joel

1998 On Reading 'World News': Apocalyptic Narrative, Negative Nationalism, and Transnational Christianity in a Papua New Guinea Society. Social Analysis 42(2):103-130.

2008 The Future is a Foreign Country: Time, Space, and Hierarchy among the Urapmin of Papua New Guinea. In Beyond the Horizon: Essays on Myth, History, Travel, and Society. Clifford Sather and Timo Kaartinen, eds. Pp. 23-36. Helsinki: Finnish Literature Society.

Robbins, Joel, and Holly Wardlow, eds.

2005 The Making of Global and Local Modernities in Melanesia: Humiliation, Transformation, and the Nature of Cultural Change. Burlington, VT: Ashgate.

Sahlins, Marshall

1992 Anahulu: The Anthropology of History in the Kingdom of Hawaii. Volume One: Historical Ethnography. Chicago: University of Chicago Press.

Stasch, Rupert 
2003 The Semiotics of World-making in Korowai Feast Longhouses. Language \& Communication 23(3/4):359-383.

2008 Referent-Wrecking in Korowai: A New Guinea Abuse Register as Ethnosemiotic Protest. Language in Society 37(1):1-25.

2009 Society of Others: Kinship and Mourning in a West Papuan Place. Berkeley: University of California Press.

2013 The Poetics of Village Space When Villages are New: Settlement Form as HistoryMaking in West Papua. American Ethnologist 40(3):555-570.

2014a Afterword: Strangerhood, Pragmatics, and Place in the Dialectics of Monster and Norm. In Monster Anthropology in Australasia and Beyond. Yasmine Musharbash and Geir Presterudstuen, eds. Pp. 195-214. New York: Palgrave Macmillan.

2014b Primitivist Tourism and Romantic Individualism: On the Values in Exotic Stereotypy about Cultural Others. Anthropological Theory 14(3):191-214.

2014c Linguistic Anthropology and Sociocultural Anthropology. In The Cambridge Handbook of Linguistic Anthropology. N.J. Enfield, P. Kockelman, and J. Sidnell, eds. Cambridge: Cambridge University Press.

2015a How an Egalitarian Polity Structures Tourism and Restructures Itself around It. Ethnos 80(4):524-547.

2015b Korowai Engagement with Ideologies of Unequal Human Worth in Encounters with Tourists, State Officials, and Education. In From "Stone-Age" to "RealTime": Exploring Papuan Mobilities, Temporalities, and Religiosities. Martin Slama and Jenny Munro, eds. Pp. 59-94. Canberra: Australian National University Press. 
Taussig, Michael

1993 Mimesis and Alterity: A Particular History of the Senses. New York: Routledge.

Taylor, Anne-Christine

2007 Sick of history: contrasting regimes of historicity in the Upper Amazon. In Time and memory in indigenous Amazonia: anthropological perspectives. Carlos Fausto and Michael Heckenberger, eds. Pp. 133-168. Gainesville, FL: University of Florida Press.

Thomas, Philip

2002 The River, the Road, and the Rural-urban Divide: A Postcolonial Moral Geography from Southeast Madagascar. American Ethnologist 29(2):366-391.

Weber, Eugen

1976 Peasants into Frenchmen: The Modernization of Rural France, 1870-1914. Stanford: Stanford University Press.

Williams, Raymond

1973 The Country and the City. Oxford: Oxford University Press.

[figure caption:]

Figure 1: Korowai lands in relation to selected Papuan towns 


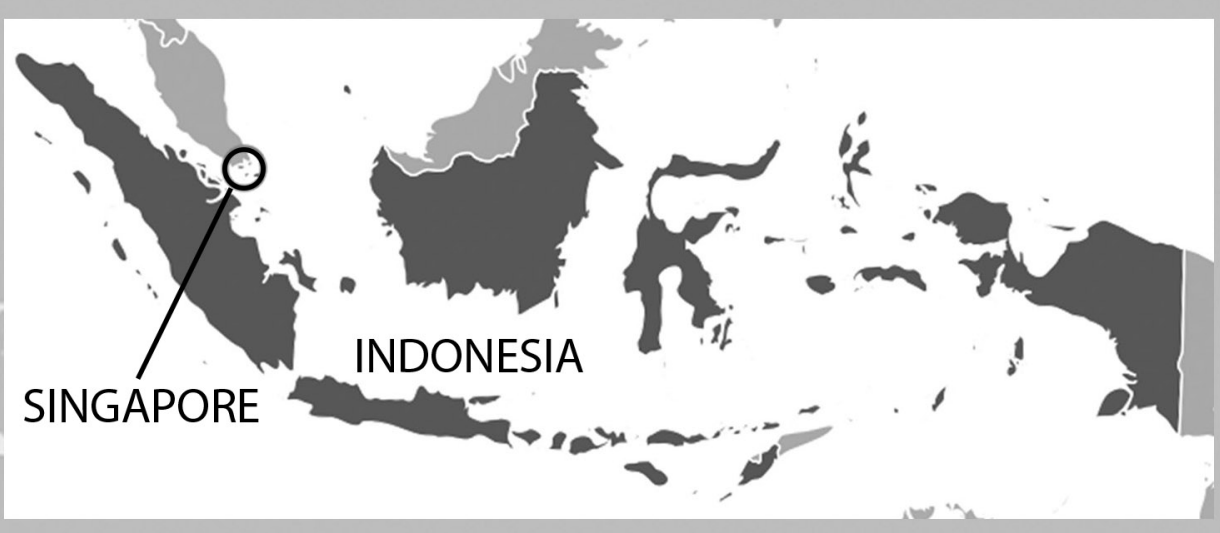

\section{PAPUA (INDONESIA)}

Jayapura

Wamena •

Korowai lands

PAPUA

NEW

GUINEA

Senggo •

Tanah

Merah

Merauke 